\section{O CINQÜENTENÁRIO DA FACULDADE DE DIREITO}

Depois de algumas reunióes preparatórias, foi fundada no dia 3 de maio de 1900 a Faculdade de Direito, hoje integrante da Universidade do Rio Grande do Sul.

A ata da terceira reunião da Congregação e Instalação solene da Faculdade Livre de Direito de Pôrto Alegre, é a seguinte:

"Aos tres dias do mez de Maio de mil e novecentos, às 3 horas da tarde, na Sala do Conselho Superior de Instrucão Publica, reunidos os Srs. Desembargadores Carlos Thompson Flôres e Epaminondas Brasileiro Ferreira, Director e Vice-Director da Faculdade, e os membros do corpo Docente, Drs. Antonio Fausto Neves de Souza, Manoel André da Rocha, Manoel Pacheco Prates, Plinio de Castro Casado, José de Almeida Martins Costa Punior, Tiastho Cerira da Rosa, Possidonio Mancio da Cunor, Timotheo Pereira da Rosa, Possidonio Mancio Ceona do Mreitas Cruz, Sebastiáo Lea e Janes F. Darcy - e na presenca do Sr. Desemar Presidente do Estado, Dr. Julio Prates de Castilhos, Dr. João José Pereira Parobé, Secretario das Obras Publicas, Dr. Montaury Leitão, Intendente Municipal, Desembargadores James de Oliveira Franco e Souza, Presidente do Superior Tribunal do Estado, Antonio Antunes Ribas e Alcibiades Cavalcanti de Albuquerque, Comissões da Congregação da Escola de Engenharia e da Faculdade de Medicina e Pharmacia, Drs. Poggi de Figueiredo, Juiz Seccional e Jardelino Goncalves de Senna, Juiz de Comarca da $3^{\text {a }}$ Vara desta Capital, Major Cherubim Febeliano da Costa Chefe de Policia do Estado. Coronel Aurelio Verissimo de Chittencourt, Secretario do Presidente do Estado, Cono de Bittentar da cintater gentina, da Republica. Oriental e do Paraguay, representantes da imprensa e innumeras pessoas gradas - O Sr. Desembargador Director abriu a sessão, declarando solemnemente instalada a Faculdade Livre de Direito de Porto Alegre. Em seguida, proferiu uma oração allusiva ao acto, e deu a palavra ao orador official da solemnidade, Dr. James F. Darcy, que leu o discurso inaugural, findo o qual o Sr. Director agradeceu a presença do sr. Presidente do Estado e das pessoas de elevada caracterisação politica e so-
Revista da Faculdade de Direito de Pôrto Alegre

cial, das Commissões das Escolas Superiores e de todos, em summa que com seu comparecimento concorreram para en sume e deu o brilho e importañio. Lavrada e assionada n'esta cidade por encer ada a sessa. Lavio de mil e noJames Farcy, Secretario, que a subsvecentos, por mim, James F. Darcy, Secretario, que a subscrevo.

\author{
Carlos Thompson Flôres \\ James F, Darcy \\ A. Borges de Medeiros \\ Germano Hasslocher \\ James de Oliveira Franco e Souza \\ Epaminondas B. Ferreira \\ Possidonio M. da Cunha Junior \\ Timotheo Pereira da Rosa \\ Antonio Antunes Ribas \\ Plinio de Castro Casado \\ Sebastião Leão \\ Manoel André da Rocha \\ Manoel Pacheco Prates \\ Leonardo Macedonia Franco e Souza \\ Alcides de F. Cruz"
}

$$
\text { ** } *
$$

Organizada a Faculdade Livre de Direito, solenemente instalada, assim se constituiu a sua administração:

Diretor - Desembargador Carlos Thompson Flôres

Diretor Desileiro Ferreira Secretário - Dr. James F. Darcy

Tesoureiro - Dr. Manoel Pacheco Prates.

As Comissões permanentes então existentes eram as seguintes:

de Contas - Desembargador Epaminondas Brasileiro Ferreira Dr. Normélio Rosa

Dr. Alcides de Freitas Cruz

Científica - Desembargador Manoel André da Rocha Dr. Plínio Alvim
Dr. Joaquim Antônio Ribeiro

da Revista - Dr. Artur Pinto da Rocha Dr. Plinio de Castro Casado Dr. Alcides de Freitas Cruz

$$
\star^{*} \text { * }
$$

o corpo docente da Faculdade, naquele ano de 1900, ficou assim constituído: 
1. ano

Filosofia do Direito - Dr. James F. Darcy

Direito Romano - Dr. Manoel Pacheco Prates

Casado
e Constitucional - Dr. Plínio de Castro

2. ano

Direito Civel - Dr. Antônio Fausto Neves de Souza

Direito Criminal - Dr. Germano Hasslocher

ireito Internacional Público e Diplomacia - Dr. Antônio Nunes Gomes Pereira

3. ano

Direito Civil - Dr. Plínio Alvim

Direito Criminal - Dr. Francisco de Paula Azevedo e Souza

Ciência das Finanças e Contabilidade do Estado - e Souza noel de Campos Cartier

Direito Comercial - Dr. Timóteo Pereira da Rosa

$4 .^{\circ}$ ano

Direito Civil - Dr. Joaquim Antônio Ribeiro

Teoria do Processo Civil, Comercial e Criminal - Dgdor.

Medicina Pública De Seira

5. ano

Prática Forense - Dgdor. Carrlos Thompson Flôres

Ciência da Administração e Direito Administrativo - Dr. Manoel de Campos Cartier

Dr. Arthur Pinto especialmente do Direito nacional -

Legislacão Comparto da Rocha

de Almeida Martins Costa Jr..

Dr. Leonardo Macedônia Franco e Souza

Dr. Normélio Rosa

Dr. Alcides de Freitas Cruz

Dr. Ricardo Pereira Machado

Dr. Antônio Carlos Pereira da Cunha

Dr. José Joaquim de Andrade Neves Netto

Dr. Antônio Marinho Loureiro Chaves

Simões Pires.

dação, a faculdade de Direito passagem do seu cinqüentenário de funu'a missa em acão de Direito fêz celebrar, na Catedral Metropolitana, S. J., assistente de drevas, oficiada pelo revmo. pe. Urbano Thiesen, Filosofia da Universidade de Historia da Filosofia da Faculdade de proferiu a oração que segue:
Revista da Faculdade de Direito de Pôrto Alegre

\section{LEX TUA MEDITATIO MEA EST}

Senhor, a Vossa Lei é a minha meditação.

Ps. 118, 77.

Excelentíssimas Autoridades.

Excelentíssimos Senhores Professôres da Faculdade de Direito. Senhoras.

Senhores.

Principiastes as solenidades do jubileu de ouro da Faculdade de Direito do Rio Grande do Sul pela celebração do sacrifício da Lei Nova. "Hic est enim Calix Sanguinis mei, Novi et Aeterni Testamenti". Por êste ato testemunhais que a vossa escola superior reconhece, acima dos artigos e dos parágrafos dos códigos, uma norma de moralidade constituida pela natureza humana, manifestada pela voz intima da consciência. Reconheceis a Lei Natural. A Lei Natural ordena o homem renda a Deus o culto da religião, culto individual e particular, culto social e público Mas, Senhores, fồrca é corrija a minha afirmacão Ponderando mais os conceitos, verifico cue cor Lei Natural não está acima da lei himana, señ̃o, diriamos, debaixo, señ̃ Nentro de tôta lei humana digna na, senao, digna deste

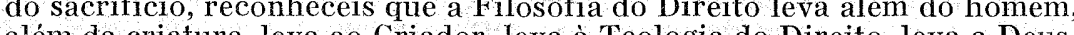
alem da etiatur, leva ao Criador, leva a Teologla do Direito, leva a Deus, razão última da Lei e do Direito. Professais o Direito Divino. Reconheceis a Lei Eterna. Na eloqüêcnia do silêncio a Lei Natural brada não ser ela a última raiz da árvore genealógica da lei das comunidades humanas e do direito das gentes. Toda a lei autêntica tira a sua origem, ùltimamente, da LEI ETERNA. A vida do jurista poderia ser definida a meditação da Lei: "Lex tua meditatio mea est". Pois o jurista medita a Lei Eterna, quando estuda a Lei e o Direito, quando ensina a Lei e o Direito, quando defende a Lei e o Direito, quando pronuncia a sentença de acôrdo com a Lei e o Direito. Será a sublime, a divina Lei Eterna o objeto direto da meditação que vos hei-de propor nesta hora em que principais a solenizar os aúreos dez lustros de trabalhos e estudos da vossa veneranda Escola Superior.

A importância, a sublimidade, a divindade da Lei evidenciar-se-á pela meditação da existência e da natureza dela.

1. Suarez, o doutor exímio, diz que todos os grandes teólogos são unânimes em admitir a existência da Lei Eterna. Os mais modernos expositores e estudiosos da Lei Eterna concordam com o teólogo espanhol. As razôes em que os teólogos alicercam a doutrina da existência da Lei Eterna são de ordem diversa. Todos Tois as dispo natureza sposiçoes da Lei Nat, como ela existe e se manifesta através da natureza humana evidenciam que ela não e so ativa, mas dada, originada de outro Ser. E' orishada a natureza himana, existente, tão marcada com o sêlo da contingencia: ontem não existiu, hoje existe, amanhã não existirá. E' originada de outro a essencial maneira de ser e a ordenação da natureza humana para o bem, para a felicidade. Eis por que o homem não pode não querer a felicidade. Originada de outro a possibilidade de eleger os meios para o fim. Como todas estas inclinações do homem, racional, dizem respeito ao intelecto e a vontade, dos quais dependeu e depende a ordem da existencia, a Lei Natural só pode depender da suprema, da pura atividade, da inteligência e da vontade suprema. E' a Lei Eterna. 

De que modo explicará a existência da Lei Natural o ateu, após
negar a existência dum ser superior, divino? como toda a contingência, a Lei Natural é . Como toda a criação, enigma inexplicável. Neste ponto torna-se manifesto ou fato, um quer superior lei divina a Lei Natural independentemente de qualo que os teólogos

razão filosófica. Provada a razão teológica assentam confirma-se pela ca explicação da Lei e da ordem natural primeiro ser inteligente, únisuprema Inteligência da ordem natural, segue-se logicamente ser a tudo se fêz. Deus é a a causa de tudo o que se têz e a razão por que haver providência do ser originado. Por conseguinte deve nador do a Lei do mundo, uma lei suprema que tudo dirige e governa tudo

O sublime pensamento da Lei Eterna, primeiro princ/pio de tôda ação, existente na sabedoria ordenadora de Deus, causa primeira d tudo o que se fêz, não foi desconhecido aos pagãos. Referindo-se à voz da consciência, que reprova o ato contrário â lei, Hesíodo diz Tanto que o homem a transgride, a lei, "a filha do Altíssimo se of ende sobe apressada aos céus, para, diante do trono do Pai, queixar-se da perversidade do sentir humano, e exigir castigo rigoroso para que paga pelos pecados dos reis",

A natureza humana, considerada como realização do pensamento divino, como imagem do exemplar divino, eterno e imutá pel, pode ser de moderno estudioso do problema ético cófocinte observação justa excelso Olimpo é o pai das leis. Demósten Sos contes diz que sòte $o$ presente dos deuses. No dizer Demostenes contemplou a lei como um escreveu as leis. e de. Cleantes. $\mathrm{X}$. as leis são implantadas pocrates segundo o qual romano, na eloquies deuses na humana natureza. $O$ orador princeps apta aduencia de sempre, diz: "Quam ob rem lex vera atque prin o vetandum ratio est recta summi Iovis" Na devem autor e defensor da lei é Varuna ou Agni. No Egito os mortos devem compareer perante a divindade, a fim de prestar contas ao jui dos malfeitores, ao conservador da lei. A sintese de todos os testemo juiz dos pagãos fá-la Heráclito ao dizer: "Tôdas as leis humanas sãomunhos tadas pela única lei divina".

2. A existência da Lei Eterna é provada por testemunhos que exprimem algo da natureza da Lei Eterna. As palavras de Heráclito sã exressa feliz de verdade sublime. Mas fôrca é realizar o propósito Antes de ex meditar a natureza da Lei Eterna.

Antes de explanar os dois conceitos precípuos ão no conhecimento da natuteza da Tomaz de Aquino, que ela é realmente idêntica à essêne advertir, com quanto a vontade, a razão e a sabedoria, como também a lei divina; por em Deus, são absolutamente a mesma cousa se perguntardes, está sujeito à Lei Eterna, respondo-vos não Se perguntardes, mais, que tertrinitária. Pois em Deus nada pode sujeita a vida insuperior. Advirto outrossim ada pode ser submetido nem sujeito a algo conhecimento da essência divina dade. A Lei Eterna, no mesmo, tão difícil como o da Divinsó se pode referir no seu carácter de norma de govêrno e regra de ação, As criaturas tornam govêrno de Deus que tem por objeto as criaturas. as criaturas tornam possível, ao yiador, conhecer a Lei Eterna Eterna, feita à mesma natureza humana a mafestáo mais exímia de Lei
O conhecimento da Lei Eterna será, pois, mediato, análogo, imperfeito, mas ainda assim verdadeiro. Tôdas as criaturas são conduzidas à sua finalidade e à sua atividade pela Lei Eterna. Em particular, o homem, capaz de conhecer a Lei Eterna, é conduzido de modo especial à consecuç̃a o do seu fim.

Depois disto, ouçamos as palavras de S. Tomaz de Aquino. Lei Eterna é a Sabedoria divina, enquanto dirige todos os atos e todos os movimentos. "Ratio divinae sapientiae, secundum quod est directiva omnium actuum et motionum". (I-II 93,1). Estas palavras põem em relêvo dois elementos da Lei Eterna. Um diz respeito à inteligência. Outro, à vontade. Fôrça é tomar juntos os dois elementos da definição. Pois a vontade só, sem 0 intelecto, teria procedimento irracional. Por seu turno o intelecto so, sem a vontade, jamais produziria nada, não elaboraria programa, não conceb livre escolha de determinada possibilidade entre muitas, como, também, que o autor do plano the queira o conteúdo. Disto se infere que o plano de govêrno do universo supõe necessàriamente a vontade do Criador que realmente escolher êste determinado mundo, entre todos os mundos possiveis, e quis fôsse executado, no tempo prefixado, o plano da criação. Mas voltemos a atencão para as funcõos das faculdades, exigidas pela definição de Lei Eterna.

$O$ intelecto. Antes de executar a obra de arte, o artista concebeThe a imagem, na mente. A imagem espiritual, assim originada, e modêlo, a medida, e, portanto, a norma de tudo o que ao depois há de ser feito. O trabalho do artista consistirá em imitar e copiar o modêlo e a imagem mental. De modo análogo, e insisto na analogia, Deus, o supremo e primeiro artista, concebeu, na eternidade, na sua mente, 0 universo, esta grande obra de arte A sabedoria divina previu, na efernidade, que f̂le, fundamento ultimo de tôda a ordem do ser etornidade, cue cor conseguinte, calisa prineira de todo o ser do unive es principios operativos, havia de produzir o mundo. Viu, também, como haveria de ondena- para o dim A lei Eterna e, por assim dizer, o prostama do governo teocratico do mundo. A Lei Eterna é o modelo, o plano segundo o qual Deus havia de gerir, no tempo, os negócios do govêrno do mundo. A Lei Eterna, assim descrita, é chamada "indicans" pelos escolásticos, porque aponta o caminho e o rumo do govêrno divino do cosmos.

Porém não basta apontar o caminho. E' necessário obrigar a seguir o rumo apontado. Êste papel cabe à vontade. Pois a vontade éo principio da ordem prática. Como Deus é a causa inteligente primeira, suprema, há de mover tôdas as cousas e o universo de modo que realize o seu programa como "gubernator omnium actuum et motionum". Pela vontade a sabedoria divina se torna a origem do movimento e a norma de tôda de tôda governação do universo. A Lei Eterna "indicans" torna-se "imperans", compulsória. A Lei Eterna é, em sintese, a Sabedoria ordenadora de Deus, vista na própria essência divina. "Dicendum quod omnis lex proficiscitur a ratione et voluntate legislatoris: lex quidem divina et naturalis a rationabili Dei voluntate"' (I-II 97,3).

A segunda explicação da natureza da Lei Eterna baseia-se na teoria do exemplarismo. As idéias divinas são a causa exemplar das essências das cousas. Conhecendo a imitabilidade da sua essência, Deus produziu e criou as cousas segundo as suas idéias (I 15 a. 2). Desta forma as cousas terrenas são imagens da idéia exemplar de Deus. A natureza humana considerada na qualidade de racional, e eminentemente imagem da idéia exemplar divina Portanto a Lei Natural que está dentro 位 Exer 
a Lei Natural, enquanto ela está na essência divina, temos a Lei Eterna. (I-II 91, 2). Se, ao invés, encararmos a Lei Eterna, enquanto ela está na essência humana, temos a Lei Natural.

Como se interpreta isto? A razão humana está para a Razão divina como a imagem está para a causa exemplar, para o modêlo. Ora o exemplar sempre é mais perfeito do que a imagem (III 56,1 ad 3). No exemplarismo, bem compreendido, exemplar e imagem nunca são numerica on existencialmente idênticos. Entre ambos pode mediar distância infinita e pode haver, ao mesmo tempo, identidade proporcional. Enquanto, pois, a razão humana, a Lei Natural, proclama a Razão divina, é idêntica a ela uma verdadeira participação dela, não obstante a distancia infinita existente entre a imagem, a Lei Natural, e o modêlo, a Lei Eterna.

Estais vendo, Senhores, que o Doutor Angélico não teve dúvida em assimilar o pensamento de Heráclito, chamando a Lei Natural participaç̃o da Lei Eterna. As duas consideracões da natureza da Lei Eterna deixam entrever a importância dela no estudo do Direito. A Lei Eterna é digno objeto da meditacão do jurista Mesmo na visão beatífica o jurista há de continuar a contemplacão da Lei Eterna e poderá dizer, jurista ha de continuar a contemplação da Lei Eter

Entretanto, antes de terminar, quisera apontar, ainda, para algumas decorrencias que fluem da nossa meditação. Sendo a razão ultima de tôda lei e de todo direito, a Lei Eterna ocupará, necessàriamente, o primeiro lugar entre tôdas as leis. Sendo idêntica à essência divina, é, como ela, imutável. Não é tudo, porém. A Lei Eterna é universal Porquanto dela dependem tôdas as outras leis e porquanto dela se originam tôdas as leis, ontolòicamente válidas, na ordem jurídica ontológica ordem jurídica ontoló ñca 0 oncontra pois lugar a divisa "PRO IURE (WRE IURE SEMPR" "PRO LECE STIPER", por ser substituida por "PRO IURE SEMPER "PRO LEGE SEMPER", porque a Lei, como o Direito e mesmo antes do Direito, esta baseada ha Lei Eterna. A Lei Eterna é universal, tambem, porque todos os seres contingentes the são sujeitos. A Lei Eterna é a LEX LEGUM, a lei das leis, a fonte das leis, porque dela se deriva a Lei Natural, humana, e a Lei sobrenatural, Divina. A lei civil, humana ou positiva, explicita a Lei Natural. A Lei eclesiástica e a interpretação e a explicitação da Lei Divina. O direito das gentes é dedução da Lei Natural. Lei Eterna est LEX LEGUM.

Senhores Professôres. Quisera que os cinco lustros heróicos da vossa existencia acadêmica vos fossem descantados, neste momento, pelos versos imortais das grandes epopéias da literatura dos povos, ou apre ciados pelo juízo dos imparciais Heródotos das nacões da terra. No entanto, rogo-vos, permiti que lembre modestamente, alguns acontecimentos dos vossos trabalhos e das vossas realizacões. Os professôres da Univers

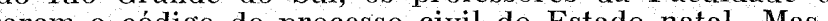
Direito, elaboraram o codigo do processo prof gloria dos formados. Se, durante o cinquientenario do vosso ser e fazer, os vossos far tão particularizador da Lei Natural e, conseguintemente, da Lei Eterna e, na expressáo do eminente jurista patrio, Paulo de Lacerda, "o maio monumento de codificação jurídica da América"; homens formados laureados pela vossa escola trabalharam, distinguindo-se entre os de mais juristas, em duas constituintes que, ambas, deram ao Brasil constituições federais segundo a Lei Natural e, portanto, segundo a Lei Eterna; homens diplomados e laureados pela Faculdade cinqüentenária do Rio Grande do Sul colaboraram na construcão do código trabalhista a que cabe 0 merito de ter seguido as normas das enciclicas "Rerum novarum" " "Quadragésimo ano", sinteses dos princípios norteadores reito do Rio Grande do Sul levaram os quilates da formação juridica reito-orandense às Conferências Católicas dos EE. UU. e às salas do Pa lácio das Nacões de Genebra; e em tôda parte, aceitos aos homens lacio das Neus, defenderam e defendem a Lei Natural e a Lei Eterna aceitos a Deus, dẽ̃ TIO MEA EST."

go após a celebração da missa, foram os professôres, alunos, ex-alunos, advogados, magistrados e autoridades presentes ao cemiterio local prestar homenagem aos professores desaparecidos. Diante do túmulo do desembargador Thompson Flores, primeiro diretor da Escola, t professor José Salgado Martins proferiu a oração evocativa da memón dos fundadores da Faculdade e dos demais professores ralecidos, moria dos fundadore discente, o bacharelando Antônio Carlos Osório.

Salão Nobre da Faculdade, realizou-se uma sessão soleÀ noite, no Salão Nof. dr. Luiz ne, sob a presidencia do Reitor Francisco Guerra Blessman, estána que representava o sr. Eloy José da Rocha, Secretario da Educacaro de Araujo, em reGovernador do Estado, Deputado Henrique Fembargador Hugo presentacão da Assembleia Legislativa do Estado, Dé Salgado Martins, Present, Presidente do Tribunal de Justiça, Prof. José Salgadouras, Diretor da Faculdade, prof. Normélio Rosa, um dos seus fundadores, Diretor dades civis, militares e eclesiásticas.

alou o DIRETOR da Faculde proferiu o discurso seguinte:

"Disse um exímio escritor, em cujo estilo ainda se reflete, discreta, nota romântica, que a imaginação possui o dom mirífico de atualizar o passado e o futuro, ressurgindo o primeiro ou antecipando o ultimo, o pastante, de

na intensidade eladora.

literátio, de enternecedora beleza, ao

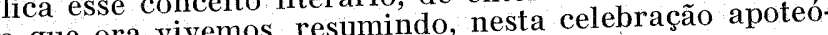
momento fugidio que ora vivemos,

tica, um passado de cinco decênios! Estamos, no pórtico dêste Transfiguram-se cenários

século, em 3 de maio de 1900 . á cinzas dos últimos fogões gaúchos

Ainda, pela campanha deserta, as cinzióes rio-grandenses, cujo chosinalam as marchas e os combarece que visava depurar a republica reque sangrento

intive consoO Rio Grande convalesce da guerra civil

lida no consenso de vencidos e va tranqüilidade, para que

Há, por tôda a parte, uma ansia de paz e abriu no velho e generoso se curem as feridas que 
Reanimam-se as atividades laboriosas que só florescem na ordem e no respeito reciproco. Organizam-se o comércio e a indústria. Repovoam-se os campos, e os seus habitantes voltam às lides da lavoura e do pastoreio onde, antes, a intensidade dos odios havia transformado em deserto.

Novas levas de imigrantes entram pelo território e já se inaugurara o regime original da colonização rio-grandense.

Panorama social tâo rico de potencialidades humanas, reclamava o ordenamento da cultura jurídica, que, aliás, já se manifestara através de estadistas rio-grandenses e cultores do direito público, cuja formação intelectual se efetuara nas velhas e nobres Faculdades de São Paulo e Recife.

O clima social e os ideais que o sulcavam, como correntes vitalizadoras, propiciaram a magnífica iniciativa da fundação de uma facul dade de direito, promovida por um grupo de ilustres magistrados e advogados.

O movimento fôra coordenado pelo Des. Carlos Thompson Flôres, mas a sua inspiraça inicial, segundo rezam as cronicas, cabe ao emnente dr. Júlio de Castilhos que, embora sucedido no govêrno pelo dr Borges de Medeiros, continuava como detentor de autoridade incontrastável no partido republicano, a que pertenciam os titulares da situação oficial.

Reuniram-se no nobre empreendimento juristas de vários quadrantes da pátria. Brasileiros dó sul e do norte, irmanados na obra comum, lançando os alicerces do ensino jurídico na nossa terra, constituem, volvidos cinco decênios, um símbolo da unidade do direito brasileiro, cujas linhas e principios fundamentais se sobrepõem à diversidade das regiões e dos vários núcleos demográficos e sociais do país, atestando a fôrça espiritual da idéia jurídica.

Qual o sentido de que se reveste a fundação de uma faculdade de direito?

Exprime, desde logo, uma ânsia ordenadora de cultura geral e de conhecimento da realidade moral e sociológica, representadas pelo homem e pelo ambiente em que se situa.

O Pio Grande do Sul, com o acentuado espírito público da sua gente, atraída sempre pela ação e pelo debate das idéias políticas, exigia, tanto ou mais do que qualquer outra unidade da federação brasileira, um instituto de ensino do direito, capaz de preparar e adestrar as mais altas inteligencias para as lides do pretório, do parlamento, da administração, da diplomacia, do magistério ou de quaisquer outras atividades em que o conhecimento jurídico constitui o instrumento mais vivo e dúctil no trato dos problemas humanos e sociais.

Mas uma Faculdade de Direito, digna dêsse nome, não é a escola em que se ensina a conhecer apenas a lei, como a preparar simples exegetas do direito positivo vigente. Este constitui um setor minimo da especulação jurídica; não é, pois, a meta do ensino ministrado nesta casa. Um ideal superior de cultura foi sempre a inspiracão suprema do doutos e saudosos mestres que elevaram e dignificaram as paredes dêste cmplo A licão perene que êles ainda professam, através do legado ínte poluto que nos transmitiram, constitui a atmosfera, o envoltório moral que nos anima.

Cada manhã, quando o professor inicia a aula habitual, parece que ao seu lado, inspirando-lhe e assistindo-The, ali está a sombra querida do velho mestre que fundou o ensino da disciplina, zelando pela pureza do patrimônio de idéias e de sentimentos que erigiu.

A sensibilidade registra êsses contatos invisíveis e o professor sente crescer a sua responsabilidade, procurando ferir com mais delicadeza e mais acêrto o instrumento que o mestre lhe deixou, ainda ressoante da última lição.

Essa linha de continuidade espiritual deve ser avivada a cada instante, sem que ela signifique imobilidade e rotina.

Que seria desta Faculdade se desaparecesse a tradicão que ora celebramos?

Mas, se o passado é a glória da instituição, o presente e o futuro the reservam o segrếdo do seu florescimento, se, refletindo os ideais do seu tempo, fôr uma fôrça de integração moral no cômputo dos verdadeiros valores.

De nada vale ensinar o direito, se êle não estiver impregnado por uma concepção da vida e do mundo, afirmativa dos valores eternos, a cujas leis não se podem eximir as construcões humanas, embora variem, com as contingências sociais, as aplicações concretas e particulares.

A vocação de uma Faculdade de Direito nâo está em transmitir conhecimentos jurídicos teóricos e práticos, de modo a habilitar profissionais na interpretacão, na aplicação, no manejo das leis. A sua vocação transcende êsse objetivo de imediatismo pragmático, para se nutrir dos ideais perenes que radicam na posição do homem diante dos seus destinos de criador de cultura e de valores, dentro de uma visão natural e sobrenatural integradora do mundo. Por isso, cabe às Faculdades de Direito, às congregacốes de juristas, aos conselhos e colégios de juízes e de advogados uma missão superior de orientaç̃o e ordenamento de sentimentos e idéias construtivas, capazes de refletir a totalidade do homem e a unidade da cultura. Disse, com razão, Luís Le Fur que, após um periodo de negação de todo o direito que não fôsse o direito positivo acabou-se por compreender que não se pode considerar o direito sem um mínimo de filosofia e mesmo de metafísica. Significa, pois, que a cultura jurídica que não se situar no quadro universal do espírito humano, ordenando-o sob o influxo do sentimento perene de justica, para a realizacão do bem comum, sera uma expressáo mutilada da vida da ordem cósmica e da ordem social.

Reverenciando os fundadores desta nobre instituição e recordando o que êles realizaram e nobilitaram, pela difusão da cultura jurídica do Rio Grande do Sul, a melhor homenagem que à sua memória poderemos prestar, nesta noite, reunidos, sob o mesmo signo de nobreza e idealidade e ao pé do mesmo fogo sagrado, é prometer-lhes que continuaremos a fazer desta Faculdade o mesmo instrumento ao serviço do direito, do bem, da verdade e da justiça."

O Professor Ruy Cirne Lima foi o orador oficial da solenidade como representante da Congregacão da Escola, tendo dito uma formosa e sugestiva oração, tecida com a história da Faculdade e com profundas e atuais reflexões jurídicas.

Pelos assistentes falou o dr. Paulo Barbosa Lessa, cujo discurso se segue:

"Invulgar o motivo que nos congrega, a todos, neste salão festivamente iluminado, quando se pense no imediatismo dos dias que correm Fis uma festividade em que se reverencia a vitória da humildade, da fé e do entusiasmo apaixonado da obra humana, em sua constante porfia contra o esgarçar nebuloso do tempo.

Aqui estamos festejando uma sobrevivência do contingente. Abrimos os nossos coracões ante o espetáculo magnífico do legado grandioso 13 - R. F. D. 
que as gerações amontoam. Deixamos nossos espíritos vagarem, despreocupados, embebendo-se nesse manancial de humanismo que outros espíritos, quase anônimos na fusão de ideais comuns e nobres, engendraram e construíram. As nossas mentes, por vêzes descrentes dos resultados dos esforços empreendidos, têm, neste momento, uma pausa de descanso na busca incessante, e encontram motivos para revigorar os ideais reviver os anseios de bom e de verdadeiro.

E' êste instante um marco de vitória cravado no terreno do humanismo. Celebra-se uma criação. Vive-se algo de concreto e duradouro. Porisso mesmo é um instante festivo. O manto do transitório, envolvendo na sagrada paz do dever cumprido tantos vultos merecedores de reverência, não foi capaz de apagar a grandiosidade de suas obras. E porque se reverencia o que está vivo, na concreta realizacão de tantas vidas pretéritas, é que êste instante é de festa, é que êste instante é de júbilo.

\section{O homem e a instituição}

Tem-se assinalado, desde a mais remota antigüidade, ser o homem um ente gregario pela sua propria natureza. Foi essa capacidade de autoconhecimento, que, por todo o sempre distinguiu os sêres da espécie humana Unicos a compreender a humildade de sun natureza ante o espuderam adatar-se às maleabilidades do meio, fugindo assim da estagnação e do extermínio.

Não se compreenderia de outra forma, sem êsse fogo divino a iluminar-lhes as mentes, a evolução contínua da espécie humana em busca de condições mais propícias ao seu diuturno empreender. Ser fisicamente inerme, o homem resistiu com galhardia aos mais diversos e terríveis cataclismos, e, procurando algo fora dêle, numa ânsia do Bom, do Verdadeiro e do Absoluto, tem escrito, ao longo da trajetória histórica, o mais heróico dos poemas.

Ser conhecedor das precariedades da própria estrutura, cônscio das limitações da sua substância, o homem, desde os primérdios de seu jornadear, procurou mitigar a própria insuficiencia na aliança com os seus semelhantes. Unificando esforços, somando possibilidades, adicionando contribuicões, foi-lhe assim possivel moldar novas formas de acão, e, de certo modo, perpetuar a transitoriedade humana, imprimindo aos trabathos comuns um plano único de realizacão. Essas tarefas de todos os dios comun un plano unico de rán obra que se realizavam e duravam em um meio social determinado, para sar expressão consagrada.

Partindo da instituiçáo natural da família, foi êle, por analogia, construindo as mais variadas sedimentações de esforços comuns. E assim se plasmaram instituições pias ou religiosas, econômicas ou culturais.

E, talvez, no auto-reconhecimento da extrema transitoriedade da existência que se poderá compreender a gênese do fenômeno institucional. A instituição representa para o homem uma aspiração de infinito, uma tentativa de construção duradoura, um alevantado anseio de se transmitir no tempo, vencendo as exíguas limitaçôes da matéria. Talvez porisso mesmo, face às instituicões cristalizadas, a alma humana se banhe, por antecipação, no espetáculo de sua própria imortalidade. E não é outra, mesmo, a explicacão de nossa euforia mental neste momento $\mathrm{em}$ que celebramos o cincuientenário dessa instituicão, para nós , en que celebra a explicas profundamente grata, que e a Faculdade de Direito da Universidade de
Pôto

\section{A Universidade e Direito}

Perde-se na voragem dos séculos, o surgimento do fenômeno institucional da Universidade. Instituição cultural, apanhava ela o esfôrco das gerações, na sublime finalidade de transmiti-lo, intato, através do tempo. Era época em que os modos de transmitir o conhecimento se apresentavam com evidentes sintomas de precariedade, face à falta de seguranca da vida humana em um mundo em que a seguranca pessoal era quase ausente, e em que a prọpria locomoção física se ressentia de era quase ausente, e em que a pros

Concentrando os esforços de cultura das gerações, aproximando os doutos e os sábios, as Universidades vêm desempenhando, desde então, transcendental papel no desenvolvimento dos povos. Plenas de humanismo, penetradas de um ideal de integridade, abarcando todo o imenso cabedal de atividades intelectivas das épocas, as Universidades têm merecido o mais acatado respeito pelo alevantado de sua missão.

Singular, contudo, é a posição específica das Faculdades de Direito no concêrto das demais atividades culturais, integradoras das Universidades. Em nenhuma outra Escola, a atividade puramente intelectiva, com laivos de universalidade, se apresenta assim tão ligada à pragmática mais imediata. Em nenhum outro setor se notará amálgama tão perfeito. De um lado, abrangendo vasta gama de problemas humanos, estudando os modos de atingir a convivência pacífica dos homens na liberdade, e mergulhando, portanto, no oceano misterioso da essência humana, a fim de lhe perscrutar a integridade; de outro lado, premidas pelas mana, a fim de lhe perscrutar a integridade; de outro lado, premidas pelas circunstâncias inadiáveis, aplicando os resultados obtidos na melhoria
das relacões de convivio social, têm realizado as Escolas de Direito um programa de atividade de nível dificilmente superável.

Adatando princípios universalmente válidos às transitoriedades e mutações do meio, as Escolas de Direito, têm, como nenhuma outra, penetrado no intimo da substância humana: sentindo já o absoluto, atendendo já ás imposições do relativo.

Daí the advém a pujança de estrutura, porque, glosando o estilista gaulês: "a cultura que não tem por contrapêso um ofício, por base uma forte vida prática, a cultura que não sente na sua carne o aguilhão da tarefa cotidiana, a cultura que não tem necessidade de ganhar o pão, perde o melhor de sua realidade: é uma flor de luxo".

\section{As Escolas de Direito e o Brasil}

Profunda tem sido a influência das Faculdades de Direito no evolver da nacionalidade. Desde os seus primórdios, a cultura nativista se desenvolveu em tôrno aos dois maiores núcleos jurídicos do país.

Primeiro no Recife, logo ao depois também em São Paulo, as Faculdades de Direito abrigaram em seu seio o que de mais puro e valioso apresentava a intelectualidade brasileira. Os bacharéis que aí plasmaram as suas culturas e que aí moldaram os seus caracteres, foram os condutores dos destinos da nacionalidade por largo espaço de tempo. De seu trabalho, de sua capacidade de seleção de processos, de sua visão das cousas de seu tempo, a História do Brasil dá atestado de valia iniludível. Já se disse que o Brasil é o país dos bacharéis. E que a sua formacão tem sido, notadamente, influenciada pelos homens da lei. Devemos notar, contudo, um arrefecimento dessa influência nos últimos tempos. Tem-se gerado, não racionalmente, uma reação à influência do bacharel no destino da pátria. Contudo, os males do bacharelismo brasileiro foram bem inferiores aos bens que êle tem construido em sua acidentada evolução. Podemos ter a certeža de que a sua atividade é imprescindí- 
vel ao bom desenvolvimento da marcha da nação. Talvez a crise que hoje atravessa a nossa pátria tenha seu ponto nevrálgico no abandono dos bons e sadios princípios de direito que eram e deverão ser o apanágio da nossa formação nacional.

Da mesma forma se expressou COSTA REGO: "Os bacharéis são em regra mal compreendidos, embora compreendam tudo. Há, entretanto, um ponto em que ninguém procura usurpar-lhes a competência: é precisamente aquêle em que se trata da organização do Estado. Afinal, a sociedade seria menos humanas sem êle, o bacharel. Figuremos a sociedade posta em fórmulas matemáticas ou mesmo nas simples fórmulas médicas. Não seria possível dentro dela a vida, feita de incorrências e fraquezas. $O$ bacharel debruça-se sôbre a fragilidade das cousas, dá-lhes um sentido filosófico, interpreta-a, acomodando-a em fórmulas menos rígidas e assim pode o mundo rolar..."

\section{A Excelência do Direito}

A uma conclusão idêntica nos levam os observadores da realidade político-social contemporânea. Diz-se que o Direito está em crise. Que os fatos se revoltam contra os códigos. Que o Direito representa apenas o pensamento da classe dominante. $\mathrm{E}$ que se tem afastado da realidade e vive emaranhado em formalismos inúteis.

Tudo isso tem, em parte, sua razão de ser. Mas a só constatacão de uma crise jurídica, prova, a contrário senso, a necessidade inadiável de sua superação. E' necessário que os fatos não mais se revoltem contra os códigos. Que o Direito atenda às aspiracões e necessidades do homem comum. Que os formalismos, não tão inúteis como à primeira vista parecem, não mais sejam do que regras antecipadas do jôgo jurídico ta parecem, na mais sejam do que ra integridade do ser humano.

"As formas legais, salientou LASKI, são respeitadas quando os homens sentem que têm em comum os grandes fins da vida". Ciência e técnica ṕode e devem marchar juntas. A êsse mesmo passo chegou GENY: "O dado deve, por sua essência mesmo, dominar o construído. Êste último, não estando justificado senão como contextura, como mei de atingir um fim superior, não deverá legitimamente contradizer êst fim. E' necessário que o artifício se esfume diante do que impõem natureza e a razão. Os elementos técnicos de elaboração jurídica cederão o passo aos elementos científicos, que trazem em si a substância mesma do Direito".

Mas êsse retôrno inadiável à harmonia entre ciência e técnica no mundo das relações inter-individuais e entre individuo e Estado, só os juristas poderão engendrar. Em suas mentes e en suas mãos estão cristalios pos pros conselentemente, poderá adatar os principios eternos da justiça aos novos fatos que o mundo contemporâneo apresenta à sagacidade dos dirigentes do povos de hoje, canalizando-os em legislação precisa.

Essa especialidade político-jurídica dos homens que fazem do $\mathrm{Di}$ reito profissão e fonte de vida é um patrimônio inalienável. A divisão do trabalho humano assim o exige. A especialização constante das atividades está a indicar. Tôda e qualquer modificação revolucionária dos moldes de vida dos sêres humanos será destituída de significação, e conduzirá mais e mais à servidão, se não fôr acompanhada da adequação aos esquemas de um Direito justo. Porque não é, afinal, calando os an seios de Absoluto, de Bom e de Verdadeiro, que o homem poderá encontrar a felicidade na terra, preservando a sua liberdade, e construindo o seu caminho de contínua perfeição
São essas consideraçôes as sugeridas por esta festividade. $E^{\prime}$ a preservação dêsse opulento patrimônio de cultura e desambicão, e não outro qualquer motivo subalterno, o que tem levado os gestores dos destinos das instituições universitárias a pugnar pela sua autonomia. A autonomia das Universidades é, realmente, condiç̃o existencial de seu bom funcionamento. Campo experimental de tôdas as teorias, ambiente onde se depuram e analisam doutrinas, na discussão alevantada e tolerante, em busca da eterna verdade, a autonomia de direção e a liberdade de cátedra the são absolutamente imprescindíveis para a consecução dos altos desígnios.

Neste momento jubiloso, em que a linha da morte é ultrapassada e em que as geracoes se encontram, as precedentes redivivas em seu trabalho duradouro e persistente, as atuais sentindo o peso dos dias passados e já contemplando uma pous de seu esfôrco cristalizado, nas to que us ritún escola, e que usuntibus dos ensiname mos contribuindo com as primicias de nossas meditacoes cientificas para a continuação das tradiçoes deste estabelecimento, tambem desejamos participar dêsse encontro, com o coração transbordando de nobres ideais.

E nesse contato com os companheiros de André da Rocha e com os continuadores de sua obra, desejamos recolher, num místico face â face, aquela mensagem que as suas vidas plasmaram: a lição de fé nos destinos da cultura gaúcha e brasileira, a lição de humildade ante os arcanos da ciência, a lição do entusiasmo ante o combate adverso da natureza contingente e precária. $E$, protegidos pela presenca sempre viva de seus espíritos, haveremos de, com a graça dos Céus, transmitir êsse glorioso patrimônio de cultura, independência e liberdade, às gerações vindouras, sob a aura de um Brasil cristão, progressista e feliz."

O acadêmico WERTER FARIA, pelo corpo discente, falou assim:

"E' a crise nas sociedades o que a doença, nas pessoas: esta não é um fato apenas somatico, nem aquela um "desajustamento incidental" (P. Sorokin). Se as relacões entre os homens e entre os Estados ressentam-se de odio e de violência, não se admita que as máquinas geram o conflito e as armas produzem a guerra.. O homem originou a crise de que reponsabiliza a civilizacão. Esmagado por ela desconhece sua culpa. Também o condenado, clamando contra a prisão, esconde oc carcerário.

Não é possível o direito renovar-se, afirma Ihering, senão rompendo com o passado. Tampouco poderemos resolver, por uma superação etico-juridica, o choque de interêsses - que a isso se reduzem os desajustamentos contemporâneos - sem fender, à semelhança do que conseguiu a Revolução Francesa com o absolutismo político, o "sistema gerador de riqueza excessiva para uns poucos e de pobreza demasiada para a maioria" ( $H$. Laski)

A solução, entretanto, fàcilmente conduz ao extermínio da liberdade, que, escreve Péguy, devemos amar mais que tôdas as cousas.

São as idéias democráticas que precisam ser realizadas na atividade econômica e na convivência social, para que a igualdade civil não seja o lôgro dos espoliados e a soberania popular a burla dos oprimidos.

A igualdade, porém, não se processa pela iliminação da propriedade, mas com o aproveitamento individual e coletivo da sua renda, e o contrôle do "poder que a acompanha" (F. Sheen). 
A revolução, que não engendra uma mentalidade, subverte as cousas. Trocaria o autocratismo industrial por uma forma oligárquica, permanecendo iguais as diferenças de classes, ou aumentadas.

O processo revolucionário atraiçoaria suas finalidades. Só o evolutivo: de adatação e mudanças, é adequado à obra que as gerações atuais encontraram para fazer.

Vinte séculos recordam as nossas obrigações para com a justiça, sem que, na realidade, aceitemos as suas exigências práticas.

Resta, agora, empreender pelo direito o que se realizaria contra

Assim como as tôrres, na frase de G. K. Chesterton, não são altas senão quando as olhamos debaixo, essa emprêsa, contemplada de um lugar como êste, não excede à possibilidade dos juristas de ultrapassarem o antagonismo das fôrças produtoras e das potências mundiais.

A oposição de classes não é uma luta pelo direito, mas pelo poder, e a contenda entre os povos não é uma necessidade de sobrevivência, sim, um embate pela hegemonia. Nenhuma visa o direito: contudo o único capaz de anulá-las, submetendo a questão aos seus princípios, que exibem o desfecho normal e equânime.

Senhores:

Reunímo-nos hoje para festejar o cinqüentenário dêste templo do ensino jurídico, num momento em que a cultura ocidental, cuja vocaensino juridico, num momento em que a cultura ocidental, cuja voca-
ça crista a diretriz do direito, se acha ameaçada pelos que a atacam e pelos que a desnaturam. de fé.

Calha, pois, que a homenagem a nossa Escola seja uma profissão

Não choraremos, como pedia Montaigne, o homem que nasce e não o moribundo - cremos no advento de uma epoca em que ninguem ser excluido dos beneficios elementares do progresso, e que as formas legais suplantarão os processos de força. Nessa, então, a humanidade recordará, com horror e vergonha, a categoria dos "despossuídos".

Mas é tempo de impedirmos que o povo tome a justiça em suas mãos.

Os demagogos não fazem leis: o direito, repitamos Ripert, é creação dos juristas.

Senhores:

Encarregadas da mais apurada formação intelectual, as faculdades de direito adquirem, na atualidade, importancia decisiva na integração de ưma nova cultura, sob cuja vigencia a vida em comum se humação de

O direito aqui professado, em 50 anos de existência do Instituto, variou, enquanto se alteravam as características da sociedade. E êle prosseguiu imutável, figurando o leito sempre igual das águas, constantemente mudadas.

Ensinou a resistência à ilegalidade e o respeito à justiça. Pode dizer como o mártir: "non obedio praecepto regis sed praecepto legis".

Se um dia, Deus não o consinta, os tesouros da sua Lei, da qual as nossas participam, padecerem o assalto da anarquia, confessaremos a nossa crença nos princípios aprendidos sob êste teto.

Nunca tergiversaremos com os nossos compromissos; lutaremos, em todos os setores humanos, pelo entendimento quando fôr possível, pela rebelião quando necessária.

Confiamos que as controvérsias entre os países deixarão de ser "abolidas" pela guerra, que, afinal, não as suprime, e as dissensões de classes, pela vingança, que as prolonga.
Valha como preito dos acadêmicos à alta Instituição Docente que esta fé no postulados jurídicos, haurida das liçóes dos seus mestres."

Tomado de visível emoção ainda falou o octogenário professor fundador NORMEIIO ROSA, que, em eloqüente improviso, rememorou grandes nomes dos seus colegas criadores da cinqüientenária Faculdade Livre de Direito, hoje Faculdade de Direito da Universidade do Rio Grande do Sul.

Foi um ato altamente significativo o descrito, pela manifestação de justiça que encerrou, e pelo brilho com que se revestiu.

\section{Homenagem na Faculdade Católica de Direito}

Por iniciativa do "Centro Acadêmico Mauricio Cardoso", a Faculdade Católica de Direito realizou uma sessão solene comemorativa da passagem do cinqüentenário da Faculdade de Direito da Universidade do Rio Grande do Sul.

Em nome do "Centro Acadêmico Mauricio Cardoso" falou o universitário Wadie Salomão, tendo sido orador oficial o professor Armando Pereira da Câmara, reitor da Universidade Católica desta capital. O professor José Salgado Martins, diretor da nossa cinqüentenária Escola, agradeceu a homenagem, tendo no mesmo sentido falado um representante do "Centro André da Rocha".

A imprensa da capital registrou a efeméride através de farto noticiário e em editoriais, que a Revista recolhe às suas páginas, rendeu homenagem à instituição benemérita.

O "Correio do Povo", de 4 de maio, publicou em editorial o seguinte:

\section{Jubileu da Faculdade de Direito}

Vimos transcorrer ontem a data de fundação da Faculdade de Direito de Pôrto Alegre. Ao ensejo da feliz efeméride, cuio transcurso assinala meio-século de existência do tradicional estabelecimento de ensino superior, iniciaram-se os atos comemorativos de que vem participando a nossa sociedade, a comecar pela piedosa romária ao túmulo dos mestres que tanto fizeram pelo bom nome da nossa cultura juridica.

Acontecimento de invulgar relêvo na vida do Estado, a passagem do cinqüentenário de fundacão da Escola de Direito de Pôto Alegre não poderia ter 0 seu significado restrito apenas ao gremio dos cue a formaram seu espírito. Tanto cuanto a numerosa classe dos as que ali os representantes do poder judiciário, os mos blico do do Estado, e a sociedade inteira, na amplitude de sua existência, na complexidade de suas relaçóes, beneficiária díreta dos resultados colhidos à sombra daquele distante evento. 
Sobrados motivos assistem à sociedade rio-grandense para solidarizar-se com as comemorações do festivo jubilèu. 0 testemunho do aprêço coletivo não poderia faltar à causa do Direito, numa data que se liga ao aparecimento entre nós do primeiro instituto destinado ao ensino dos princípios e normas que se criaram exatamente para possibilitar a vida social, objetivando o bem-estar e a tranqüilidade que só podem ser auferidos sob a égide da lei, que a todos garante a igualitária distribuição de justiça, como fundamento da dignidade humana, onde se alicerça a felicidade dos indivíduos e dos povos.

Inaugurada sob tão altos auspícios, pôde a nossa Faculdade de Direito, no decurso dêstes cinqüenta anos, votar-se ao integral cumprimento de suas finalidades quer como centro de cultura que sempre teve a seu serviço a probidade e ilustração de grandes mestres, quer como forja de valores representativos do desenvolvimento que trouxe à intelectualidade indígena, no domínio das letras juridicas, no exercicio profissional, ou na vida pública. Em qualquer dêsses setores, embora "muito nal, ou na vida pública. Em qualquer dêsses setores, embora muito caracteriza, abundam os frutos do trabalho que há meio-século vem desenvolvendo a Faculdade de Direito de Pôrto Alegre.

Conferindo o grau universitário às sucessivas turmas que têm passado por suas bancas, a nossa Faculdade de Direito não se limita a formar bacharéis imbuídos de espírito livresco, cuja finalidade fôsse a posse exclusiva de um título a que não correspondessem maiores obrigacões para com a sociedade. Tão leviana suposiç̃o encontraria formal des pantido na polimorfa influência que o instituto de cultura superior, cujo jubilen se vema interion instituiç̃ó que nos regem e que são a mais sólida base de nossa vocação para o progresso.

O "Diário de Noticias", de 8 de maio, lançou o seguinte editorial:

\section{Cinquienta anos de consagração ao direito}

Rui Barbosa, referindo-se ao seu jubileu profissional, justamente glorificado, na época, como um dos mais notáveis acontecimentos intelectuais da História do Brasil, assim inicia a sua famosa "Oração aos Moços" - jóia tribunicia que, para o nosso país e o nosso tempo, representa algo de comparável à "Oração à Coroa", de Demóstenes "Não quis Deus que os meus cinquienta anos de consagração ao direito viessem receber, no templo do seu ensino, em São Paulo, o sêlo de uma grande bềnção."

No Rio Grande do Sul, a data que hoje transcorre, assinala, por igual, outro jubileu, outros "cinqüenta anos de consagração ao direito". Com esta diferença, porém, não se trata apenas de uma vida, embora uma grande vida como a de Rui, mas de um conjunto de muitas vidas ilustres, que se vêm nobremente sucedendo a servico de uma instituiĨ̃o votada ao venting Universidade do Rio Grande do Sul que comemora o cinqüentenário de sua fundação, solenizada a 3 de maio de 1900 .

A idéia, logo corajosamente corporificada, amanhecera com o Século XX, no extremo sul do país. Sentia-se, então, intensamente a falta de uma escola de direito, pois poucos eram os que podiam ir cursar a tradicional Faculdade de São Paulo. Tamanha era a escassez de sul- riograndenses diplomados em ciências jurídicas e sociais que, por muito tempo, grande era o número de brasileiros de outros Estados, especialto Estado. E, na advocacia, immente do nordeste, na masistrat Trual de Justica perava o autodidatismo. Epoca houve que nortistas.

O ensino do direito constituía, assim, um imperativo decorrente do desenvolvimento e do progresso do Rio Grande. Aos abnegados e lúci dos fundadores da antiga Faculdade de Direito de Pôrto Alegre deve por conseguinte, a comunidade gaúcha um grande e alto serviço: o de por com dotado nosso Estado de um instituto que, nos seus cinqüenhaveritos e brilhante contrita años de é atestado pelo relêvo alcançado, na buiça a cultura brasilar, elevadas funç̃es, por vida publica e particular, Hiversidade do Rio Grande gressos da atual Fald ếles mesmo, do Sul, entre cujos grandes batalhador é de justiça proclama-lo - cumpre destacar o professor emérito desempelo jurista e professor emerito, o qual professava verdadeira devoção pelo estabelecimento que durante largo período dirigiu.

Aliás, a contribuição da Faculdade de Direito da URGS ao ensino superior não se limitou ao campo do direito; estendeu-se ao campo da economia, a ela se devendo a fundação, em 1909, da antiga Escola Superior de Comércio, que por muitos anos funcionou anexa àquela $\mathrm{Fa}$ puldade, para hoje constituir um dos institutos autônomos da Universicula e panomia e Administração.

Da Faculdade de São Paulo disse Rui Barbosa que é "o templo do ensino do direito", naquela cidade O mesmo se pode dizer da Faculdaensino do dito , nacito um verde de Posta e venerado pelas gedadeiro templo algo de

Na verdade trata-se de uma instituição que, embora venha a passar Na verdade, trata-se de uma para a orbita da união, com a nual cumprirá constantemente apoiá-la orgulho para o Rio Grande, ao qual demais institutos que integram a e prestigiá-la, a fim de que, com os demais institutos que contribuição à cultura nacional.

\section{Concursos realizados}

De 9 a 12 de maio realizou-se o concurso para Livre Docência da cadeira de Medicina Legal, tendo concorrido o dr. Celso Cezar Papaléo, cadeira de Mudesé Salgado Martins, Franque teve có Sim Fábio Nascimento Barros, Raymundo Gonçalves Viana e Celso Machado de Aquino.

Celso Mache apresentada pelo candidato se subordinava ao título "Psicopatas e neuróticos em face do Direito Penal", e a sua defesa despertou patas e neurôticos én sôbre o "Estudo médico legal grande interêsse. A prova didatica versou sobre o "Estudo me co conduta do perito do simulador e do dissimulador" e a escrita sôbre a "Conduta do perito nos casos de envenenamento".

A média obtida pelo dr. Celso Cezar Papaléo foi 9,2.

*

Também foi provida a cátedra de Economia Política, com a aprocão do dr. as provas de 23 a 28 de junho. 
A comissão examinadora estava presidida pelo diretor da Faculdade, prof. José Salgado Martins, e era compostá pelos professôres Jobim Meirelles.

A tese - "O corporativismo no campo da Economia" - foi defen-
ida durante cinco horas, esgotando-se o tempo regulament dida durante cinco horas, esgotando-se o tempo regulamentar. A prova foi relativa ao ponto "Populacão econômica do transporte" e a didática 0 dr. Mem de Sá conquistou emigração e imigração".

\section{CONGRESSO JURÍDICO}

Para comemorar o cinqüentenário da Faculdade de Direito, assim como o centenário do Código Comercial, a direção da Faculdade decidiu realizar um congresso juridico.

O certame, que contará com a colaboração e a presença de notáveis juristas do continente, será instalado no dia 11 de agôsto, data aniversária da instituição dos cursos jurídicos no Brasil.

E' o seguinte o

\section{TEMÁRIO DO CONGRESSO}

- Direito Mercantil -

1. ${ }^{\mathrm{a}}$ PARTE

Estudos sôbre o Código de 1850

ORIENTACÃO QUE PRESIDIU A FEITURA DO CÓDIGO COMERCIAL DE 1850 :

a) quanto à concepção político-jurídica da disciplina

b) quanto à técnica legislativa;

c) quanto ao critério de delimitação da matéria.

2. O DIREITO COMERGIAL BRASILEIRO CONSUETUDINÁRIO NA CENTÚRIA DE 1850 A 1950 :

a) das realizacõos da prática contratual

d) da elaboração da doutrina;

c) das aquisições da jurisprudência.

3. SENTIDO DA LEGISLACÃO SUPERVENIENTE, INTEGRADORA E DERROGATÓRIA DO CÓDIGO:

a) as idéias gerais dêste;

b) a concepcão político-jurídica da disciplina;

c) a delimitação da matéria considerada mercantil;

d) a técnica legislativa.

4. CARACTERES GERAIS DO DIREITO COMERCIAL BRASILEIRO VIGENTE: 